\title{
Adoptive T Cell Therapy for Epstein-Barr Virus Complications in Patients With Primary Immunodeficiency Disorders
}

\author{
Lauren P. McLaughlin ${ }^{1,2}$, Catherine M. Bollard ${ }^{1,3,4}$ and Michael D. Keller ${ }^{1,3 *}$ \\ ${ }^{1}$ Center for Cancer and Immunology Research, Children's National Health System, The George Washington University, \\ Washington, DC, United States, ${ }^{2}$ Division of Oncology, Children's National Health System, Washington, DC, United States, \\ ${ }^{3}$ Division of Allergy and Immunology, Children's National Health System, Washington, DC, United States, ${ }^{4}$ Division of Blood \\ and Marrow Transplantation, Children's National Health System, Washington, DC, United States
}

OPEN ACCESS

Edited by:

Isabelle Meyts,

KU Leuven, Belgium

Reviewed by:

Mark Ballow,

University of South Florida,

United States

Tomohiro Morio,

Tokyo Medical and Dental

University, Japan

*Correspondence:

Michael D. Keller

mkeller@childrensnational.org

Specialty section:

This article was submitted to Primary Immunodeficiencies,

a section of the journal

Frontiers in Immunology

Received: 22 January 2018 Accepted: 05 March 2018

Published: 19 March 2018

Citation: McLaughlin LP, Bollard CM and Keller MD (2018) Adoptive T Cell Therapy for Epstein-Barr Virus

Complications in Patients

With Primary Immunodeficiency

Disorders.

Front. Immunol. 9:556. doi: 10.3389/fimmu.2018.00556
Patients with primary immunodeficiency disorders (PID) have an increased risk from acute and chronic Epstein-Barr Virus (EBV) viral infections and EBV-associated malignancies. Hematopoietic stem cell transplantation (HSCT) is a curative strategy for many patients with PID, but EBV-related complications are common in the immediate post-transplant period due to delayed reconstitution of $T$ cell immunity. Adoptive $T$ cell therapy with EBV-specific T cells is a promising therapeutic strategy for patients with PID both before and after HSCT. Here we review the methods used to manufacture EBV-specific T cells, the clinical outcomes, and the ongoing challenges for future development of the strategy.

Keywords: primary immunodeficiency disorders, Epstein-barr virus, adoptive T cell therapy, immunotherapy, hematopoietic stem cell transplantation

\section{BACKGROUND}

Epstein-Barr Virus (EBV) is a herpes virus that typically causes a mild to moderate self-limiting viral illness in healthy individuals. During primary infection, EBV establishes latency in B lymphocytes and oral epithelial cells. The level of B lymphocytes latently infected is maintained at a very low level through a potent cell-mediated immune response by EBV-specific T lymphocytes (1). However, individuals with moderate to severe forms of primary immunodeficiency disorders (PID) have weakened T-cell immunity with diminished immunosurveillance. PID patients are at risk from EBV-related complications which include acute and chronic infections and EBV-associated malignancies. EBV is also a frequent inciting factor for hemophagocytic lymphohistiocytosis (HLH) in PID with impaired cell-mediated cytotoxicity.

Hematopoietic stem cell transplantation (HSCT) has been used as curative approach for severe combined immunodeficiency (SCID) for over 50 years, and the approach is increasingly being used for other PIDs $(2,3)$. However, reconstitution of T cell immunity, needed to control both acquired viral infections reactivating viruses, is delayed for up to 6 months after transplantation. During this period patients remain extremely vulnerable to viral complications. While antiviral pharmacotherapy is available for many of the viruses that contribute to pre- and post-HSCT morbidity and mortality, their use is limited by toxicities and emerging resistance. Rituximab, a monoclonal antibody targeting CD20, has good efficacy against EBV. However, Rituximab targets not only the EBV-infected B cells, but also the healthy B cell compartments, which further weakens the immune system. Resistance to rituximab has also been described (4). Given these limitations, adoptive therapy with EBV-specific T cells has emerged as a promising therapeutic strategy for PID patients with EBV-related complications. 
Adoptive therapy with viral-specific T cells (VSTs) has been used for over 20 years $(5,6)$. Earliest experience using cellular therapy for EBV-related post-transplant lymphoproliferative disease (PTLD) after HSCT included using unmanipulated donor lymphocyte infusions, which was often effective, but carried a high risk of graft-versus-host disease (GVHD) (7). Subsequently, VSTs have been developed that show safety and efficacy in treating EBV infections while minimizing the risk of GVHD (8-13). While previous reviews have primarily examined the use of all forms of VSTs for patients with PID $(14,15)$, this review focuses specifically on the development of and clinical use of EBV-specific T cells for patients with PID.

\section{EBV-SPECIFIC T CELL GENERATION METHODS}

Several methods have been developed to generate EBV-specific $\mathrm{T}$ cell products with minimally alloreactive $\mathrm{T}$ cells to decrease the risk of GVHD. These techniques include ex vivo expansion, multimer selection, and IFN- $\gamma$ capture. To date, ex vivo expansion is the most commonly used method.

Many ex vivo expansion methods use EBV-transformed lymphoblastoid cell lines (LCL) as antigen presenting cells (APCs). LCLs are advantageous APCs as they express all $10 \mathrm{EBV}$ latency antigens (type III latency), but also high levels of class I and II HLA and co-stimulatory molecules (16). Either activated monocytes or dendritic cells are used in the first stimulation, with LCLs used for subsequent stimulations. To further refine this technique, groups have developed methods for modifying LCL by either pulsing with synthetic peptide pools encompassing viral antigens, or transducing LCLs with adenovirus vectors that overexpress either latent membrane protein (LMP) 2 or LMP1 and LMP2. These strategies enhance T cell specificities for the less immunogenic EBV antigens LMP1 and LMP2 increasing their efficacy for EBV-related lymphomas that only express LMP1 and LMP2 (type II latency). While this method has proven to be safe and efficacious, it takes at least 8 weeks to generate a product suitable for clinical use as LCL take 3-4 weeks to manufacture. This has spurred the development of rapid ex vivo culture methods using a single stimulation with APC pulsed with synthetic peptide pools, or direct stimulation of PBMCs with synthetic peptide pools. These methods reduce the manufacturing time to 10-14 days. Rapid ex vivo culture methods have been used for multivirus specific $\mathrm{T}$ cells, but not for $\mathrm{T}$ cell products specific for EBV only.

Additional techniques, such as multimer selection or IFN- $\gamma$ capture, can produce VSTs even more readily than rapid ex vivo culture (17-19). Multimer selection uses magnetically labeled peptide multimers to isolate $\mathrm{T}$ cells specific for the relevant peptide/MHC multimers. IFN- $\gamma$ capture uses an immunomagnetic separation device to isolate T cells that produce IFN- $\gamma$ when stimulated by viral antigens. Although these techniques produce a clinical grade product within $48 \mathrm{~h}$, they require donors not only to be seropositive to the virus of interest, but also to have a detectable level of circulating virus specific T cells. Leukapheresis is typically needed to collect enough $\mathrm{T}$ cells for clinical use. While IFN- $\gamma$ capture is not HLA-restricted and produces a polyclonal and polyfunctional product containing $\mathrm{CD}^{+}$and $\mathrm{CD}^{+} \mathrm{T}$ cells, multimer selection is an HLA-restricted process, and generally yields only $\mathrm{CD}^{+} \mathrm{T}$ cells.

\section{PREVIOUS CLINICAL USAGE OF EBV- SPECIFIC T CELLS FOR PID DISORDERS}

\section{Donor-Derived EBV-Specific T Cells}

As PID is one of the most common non-malignant indications for referral to HSCT in pediatrics and is associated with high risk for viral complications, patients with PID constitute a sizeable proportion of patients in VST clinical trials (Table 1). A large, multi-center study with a median follow-up of 10 years treated 114 patients with EBV-specific T cells after HSCT, either for prophylaxis $(n=101)$ or treatment $(n=13)$ and included 13 patients with PID. All patients treated as prophylaxis had no subsequent EBV viremia, while three patients with active disease attained a complete response (CR) and three additional patients achieved a PR (10). Papadopoulou et al. included four patients with PID in their clinical trial of multivirus-specific $\mathrm{T}$ cells (CMV, EBV, AdV, HHV6, BK), two of whom received $\mathrm{T}$ cells for EBV-related complications and both of whom obtained a CR (20).

In a large retrospective review of 36 PID patients receiving VSTs, Naik et al. included four patients with IL2RG-SCID as well as patients with Wiscott-Aldrich and combined immunodeficiency disorder (CID) who received donor-derived-specific $\mathrm{T}$ cells for prophylaxis. All patients remained free of EBV viremia after receiving $\mathrm{T}$ cells (14). Additionally, one patient with HLH received donor-derived trivirus VSTs (CMV, EBV, Adv) for CMV and EBV viremia with clearance of both viruses.

\section{Third Party EBV-Specific T Cells}

To make cellular therapy more readily available, there is growing interest in establishing third-party banks of VSTs. Such T cell therapeutics produced from healthy donors are available for "off-the-shelf" use, eliminating the time and cost associated with custom-made products. These would be particularly beneficial in the setting of T-cell depleted transplantation, or when EBVnaive donors are the sole option for an EBV-seropositive patient, which would impart high risk of viral reactivation particularly in those with prior EBV-associated disease. While there is limited experience with third party banks to date, the results have been promising, particularly in patients with PID (Table 2).

Vickers et al. established a large third party bank of EBVspecific $\mathrm{T}$ cells to treat patients with PTLD and other EBV complications after HSCT or solid organ transplantation. To date, they have treated three patients with PIDs, including combined immune deficiency and chronic granulomatous disease (CGD). One patient had a CR, but the other two died from progressive disease (PD). At the time of publication, one additional patient with CGD had not undergone HSCT, but had EBV-specific T cells matched for use after transplantation (22). Two patients with CTP synthase 1 (CTPS1) deficiency have been treated with third party EBV-specific T cells for EBV-LPD and primary CNS lymphoma, 
TABLE 1 | Previous clinical use of donor-derived EBV-specific T cells.

\begin{tabular}{|c|c|c|c|c|c|c|c|}
\hline Reference & $\begin{array}{l}\text { Primary } \\
\text { immunodeficiency } \\
\text { disorders diagnosis }\end{array}$ & Indication & Specificity & Generation method & Source & Cell Dose & Outcomes \\
\hline Leen et al. (21) & SCID & Prophylaxis & EBV, AdV & $\begin{array}{l}\text { Culture, } \\
\text { lymphoblastoid } \\
\text { cell lines (LCL) with } \\
\text { Ad5f35 vector }\end{array}$ & $\begin{array}{l}\text { Hematopoietic stem cell } \\
\text { transplantation (HSCT) donor, } \\
\text { peripheral blood }\end{array}$ & $1.35 \times 10^{8} / \mathrm{m}^{2}$ & $\begin{array}{l}\text { Alive, no active } \\
\text { infections }\end{array}$ \\
\hline \multirow[t]{3}{*}{$\begin{array}{l}\text { Papadopoulos } \\
\text { et al. ( } 7 \text { ) }\end{array}$} & GATA2 deficiency & EBV, BK & $\begin{array}{l}\text { CMV, EBV, } \\
\text { AdV, HHV6, } \\
\text { BK }\end{array}$ & Culture, peptide & HSCT donor, peripheral blood & $2 \times 10^{7} / \mathrm{m}^{2}$ & $\mathrm{CR}$ \\
\hline & SCID variant & BK, EBV & $\begin{array}{l}\text { CMV, EBV, } \\
\text { AdV, HHV6, } \\
\text { BK }\end{array}$ & Culture, peptide & HSCT donor, peripheral blood & $2 \times 10^{7} / \mathrm{m}^{2}$ & $\mathrm{CR}$ \\
\hline & $\mathrm{HLH}$ & $\begin{array}{l}\text { HHV6, BK; } \\
\text { subsequent } \\
\text { EBV reactivation }\end{array}$ & $\begin{array}{l}\text { CMV, EBV, } \\
\text { AdV, HHV6, } \\
\text { BK }\end{array}$ & Culture, peptide & HSCT donor, peripheral blood & $1 \times 10^{7} / \mathrm{m}^{2}$ & $\begin{array}{l}\text { HHV6: CR; BK: } \\
\text { NR; EBV: CR }\end{array}$ \\
\hline \multirow{13}{*}{$\begin{array}{l}\text { Heslop } \\
\text { et al. (10) }\end{array}$} & XLP & Prophylaxis & EBV & Culture, LCL & HSCT donor, peripheral blood & $2 \times 10^{7} / \mathrm{m}^{2}$ & No viremia \\
\hline & $\mathrm{CID}$ & Prophylaxis & EBV & Culture, LCL & HSCT donor, peripheral blood & $2.5 \times 10^{7} / \mathrm{m}^{2}$ & No viremia \\
\hline & WAS & Prophylaxis & EBV & Culture, LCL & HSCT donor, peripheral blood & $2.5 \times 10^{7} / \mathrm{m}^{2}$ & No viremia \\
\hline & XLP & Prophylaxis & EBV & Culture, LCL & HSCT donor, peripheral blood & $2 \times 10^{7} / \mathrm{m}^{2}$ & No viremia \\
\hline & XLP-like & Prophylaxis & EBV & Culture, LCL & HSCT donor, peripheral blood & $2 \times 10^{7} / \mathrm{m}^{2}$ & No viremia \\
\hline & WAS & EBV viremia & EBV & Culture, LCL & HSCT donor, peripheral blood & $2 \times 10^{7} / \mathrm{m}^{2}$ & $\mathrm{CR}$ \\
\hline & SCAEBV/NK defect & EBV viremia & EBV & Culture, LCL & HSCT donor, peripheral blood & $1 \times 10^{8} / \mathrm{m}^{2}$ & $\mathrm{CR}$ \\
\hline & SCAEBV & EBV viremia & EBV & Culture, LCL & HSCT donor, peripheral blood & $2 \times 10^{7} / \mathrm{m}^{2}$ & $\begin{array}{l}\text { PR; died of } \\
\text { progressive } \\
\text { lymphoma }\end{array}$ \\
\hline & SCAEBV & EBV viremia & EBV & Culture, LCL & HSCT donor, peripheral blood & $2 \times 10^{7} / \mathrm{m}^{2}$ & $\begin{array}{l}\text { No further EBV } \\
\text { reactivation }\end{array}$ \\
\hline & XLP (SLAM mutation) & EBV viremia & EBV & Culture, LCL & HSCT donor, peripheral blood & $2 \times 10^{7} / \mathrm{m}^{2}$ & $\mathrm{CR}$ \\
\hline & XLP & EBV viremia & EBV & Culture, LCL & HSCT donor, peripheral blood & $2 \times 10^{7} / \mathrm{m}^{2}$ & PR \\
\hline & XLP & EBV viremia & EBV & Culture, LCL & HSCT donor, peripheral blood & $2 \times 10^{7} / \mathrm{m}^{2}$ & $\mathrm{CR}$ \\
\hline & XLP & EBV viremia & EBV & Culture, LCL & HSCT donor, peripheral blood & $2 \times 10^{7} / \mathrm{m}^{2}$ & $\mathrm{PR}$ \\
\hline \multirow[t]{2}{*}{$\begin{array}{l}\text { Doubrovina } \\
\text { et al. (12) }\end{array}$} & XLP & EBV-LPD & EBV & Culture, LCL & HSCT donor, peripheral blood & $\begin{array}{c}1 \times 10^{6} / \mathrm{kg} \times 3 \\
\text { doses }\end{array}$ & PD; died \\
\hline & ALPS & EBV-LPD & EBV & Culture, LCL & HSCT donor, peripheral blood & $1 \times 10^{6} / \mathrm{kg}$ & NE; died \\
\hline \multirow[t]{5}{*}{ Naik et al. (14) } & IL2RG-SCID & Prophylaxis & $\begin{array}{l}\text { CMV, EBV, } \\
\text { AdV }\end{array}$ & $\begin{array}{l}\text { Culture, DC, and } \\
\text { LCL with Ad5f35f- } \\
\text { CMVpp65 vector }\end{array}$ & HSCT donor, umbilical cord & $1.5 \times 10^{7} / \mathrm{m}^{2}$ & No viremia \\
\hline & IL2RG-SCID & Prophylaxis & $\begin{array}{l}\text { CMV, EBV, } \\
\mathrm{AdV}\end{array}$ & $\begin{array}{l}\text { Culture, DC, and } \\
\text { LCL with Ad5f35f- } \\
\text { CMVpp65 vector }\end{array}$ & HSCT donor, umbilical cord & $2.5 \times 10^{7} / \mathrm{m}^{2}$ & No viremia \\
\hline & IL2RG-SCID & Prophylaxis & $\begin{array}{l}\text { CMV, EBV, } \\
\text { AdV }\end{array}$ & $\begin{array}{l}\text { Culture, DC, and } \\
\text { LCL with Ad5f35f- } \\
\text { CMVpp65 vector }\end{array}$ & HSCT donor, umbilical cord & $1 \times 10^{7} / \mathrm{m}^{2}$ & No viremia \\
\hline & IL2RG-SCID & Prophylaxis & $\begin{array}{l}\text { CMV, EBV, } \\
\text { AdV }\end{array}$ & $\begin{array}{l}\text { Culture, DC, and } \\
\text { LCL with Ad5f35f- } \\
\text { CMVpp65 vector }\end{array}$ & HSCT donor, umbilical cord & $1 \times 10^{7} / \mathrm{m}^{2}$ & No viremia \\
\hline & WAS & Prophylaxis & $\begin{array}{l}\text { CMV, EBV, } \\
\text { AdV }\end{array}$ & $\begin{array}{l}\text { Culture, DC, and } \\
\text { LCL with Ad5f35f- } \\
\text { CMVpp65 vector }\end{array}$ & HSCT donor & $1 \times 10^{7} / \mathrm{m}^{2}$ & No viremia \\
\hline
\end{tabular}


TABLE 1 | Continued

\begin{tabular}{|c|c|c|c|c|c|c|c|}
\hline Reference & $\begin{array}{l}\text { Primary } \\
\text { immunodeficiency } \\
\text { disorders diagnosis }\end{array}$ & Indication & Specificity & Generation method & Source & Cell Dose & Outcomes \\
\hline & CID & Prophylaxis & EBV & Culture, peptide & HSCT donor & $2.5 \times 10^{7} / \mathrm{m}^{2}$ & No viremia \\
\hline & HLH (STXBP2) & CMV, EBV & $\begin{array}{l}\text { CMV, EBV, } \\
\text { AdV }\end{array}$ & Culture & HSCT donor & $\begin{array}{c}1 \times 10^{7} / \mathrm{m}^{2} \times 2 \\
\text { doses }\end{array}$ & $\begin{array}{l}\text { CMV: CR; EBV: } \\
\text { CR }\end{array}$ \\
\hline & WAS & Prophylaxis & $\begin{array}{l}\text { CMV, EBV, } \\
\text { AdV }\end{array}$ & Culture & HSCT donor & $2 \times 10^{7} / \mathrm{m}^{2}$ & No viremia \\
\hline
\end{tabular}

SCID, severe combine immunodeficiency; EBV, Epstein-barr virus; AdV, adenovirus; CMV, cytomegalovirus; HHV6, human herpesvirus 6; CR, complete response, HLH, hemophagocytic lymphohistiocytosis; NR, no response; XLP, X-linked lymphoproliferative disease; CID, combined immune deficiency; WAS, Wiskott-Aldrich syndrome; SCAEBV, severe chronic active EBV; ALPS, autoimmune lymphoproliferative syndrome; $D C$, dendritic cell.

TABLE 2 | Previous clinical use of third party Epstein-Barr Virus (EBV)-specific T cells.

\begin{tabular}{|c|c|c|c|c|c|c|c|}
\hline Reference & $\begin{array}{l}\text { Primary immunodeficiency } \\
\text { disorders diagnosis }\end{array}$ & Indication & Specificity & $\begin{array}{l}\text { Generation } \\
\text { method }\end{array}$ & Source & Cell dose & Outcomes \\
\hline \multirow[t]{3}{*}{$\begin{array}{l}\text { Vickers } \\
\text { et al. (22) }\end{array}$} & $\begin{array}{l}\text { Combined immunodeficiency } \\
\text { disorder (CID) }\end{array}$ & PTLD & EBV & Culture, LCL & Third party & $\begin{array}{c}1-2 \times 10^{6} / \mathrm{kg} / \text { dose } ; 4 \text { doses } \\
\text { given weekly }\end{array}$ & $\mathrm{CR}$ \\
\hline & CGD & PTLD & EBV & Culture, LCL & Third party & $\begin{array}{c}1-2 \times 10^{6} / \mathrm{kg} / \text { dose } ; 4 \text { doses } \\
\text { given weekly }\end{array}$ & PD; died \\
\hline & CID & PTLD & EBV & Culture, LCL & Third party & $\begin{array}{c}1-2 \times 10^{6} / \mathrm{kg} / \text { dose } ; 4 \text { doses } \\
\text { given weekly }\end{array}$ & PD; died \\
\hline $\begin{array}{l}\text { Wynn } \\
\text { et al. (23) }\end{array}$ & CTPS1 deficiency & $\begin{array}{l}\text { Primary CNS } \\
\text { lymphoma }\end{array}$ & EBV & Culture, LCL & Third party & $\begin{array}{l}2 \times 10^{6} / \mathrm{kg} / \text { dose; } 7 \text { doses given } \\
\text { weekly; } 2 \text { additional doses after } \\
\text { re-emergence of EBV disease }\end{array}$ & $\mathrm{CR}$ \\
\hline $\begin{array}{l}\text { Doubrovina } \\
\text { et al. (12) }\end{array}$ & $\begin{array}{l}\text { Hemophagocytic } \\
\text { Iymphohistiocytosis (HLH) }\end{array}$ & EBV-LPD & EBV & Culture, LCL & Third party & $1 \times 10^{6} / \mathrm{kg} \times 3$ doses & $\mathrm{CR}$ \\
\hline \multirow[t]{3}{*}{$\begin{array}{l}\text { Naik } \\
\text { et al. (14) }\end{array}$} & $\begin{array}{l}\text { ADA-severe combined } \\
\text { immunodeficiency }\end{array}$ & EBV-LPD & $\begin{array}{l}\text { CMV, EBV, } \\
\text { AdV }\end{array}$ & Culture & $\begin{array}{l}\text { Third party, pre- } \\
\text { hematopoietic } \\
\text { stem cell } \\
\text { transplantation }\end{array}$ & $5 \times 10^{6} / \mathrm{m}^{2}$ & $\begin{array}{l}\text { NR, died from } \\
\text { EBV-LPD }\end{array}$ \\
\hline & $\mathrm{HLH}$ & EBV & EBV & Culture & Third party & $2 \times 10^{6} / \mathrm{kg} \times 3$ doses & PR; died of PTLD \\
\hline & CTPS1 deficiency & EBV-LPD & EBV & Culture & Third party & $2 \times 10^{6} / \mathrm{kg} \times 2$ doses & $\mathrm{CR}$ \\
\hline $\begin{array}{l}\text { Withers } \\
\text { et al. (24) }\end{array}$ & SCAEBV & EBV & EBV & Culture & Third party & $2 \times 10^{7} / \mathrm{m}^{2}$ & EBV: NR; Died \\
\hline
\end{tabular}

CGD, chronic granulomatous disease; PTLD, post-transplant lymphoproliferative disease; PD, progressive disease; CTPS1, CTP synthase 1 deficiency; EBV-LPD,

EBV-lymphoproliferative disease; $P R$, partial response.

and both had CRs after T cell therapy $(14,23)$. Third party EBVspecific T cells have also been used in HLH as discussed below.

\section{SPECIAL CASES}

\section{Pretransplantation}

As patients with PID are particularly vulnerable to chronic and refractory viral infections even prior to HSCT (25-27), another benefit of third party $\mathrm{T}$ cells is the ability to treat patients prior to transplant. This would not only minimize mortality associated with transplant, but could allow more patients to be referred to transplant. Naik et al. described two patients with PID (one with SCID and another with CTPS1 deficiency) with partially HLAmatched third-party $\mathrm{T}$ cells prior to HSCT for EBV-LPD, one of whom achieved a CR $(14,22,23)$. A patient with ADA-SCID who developed EBV viremia and CMV colitis while on enzyme replacement therapy was treated with trivirus VSTs (CMV, EBV, AdV) that were 5/10 HLA matched with the patient, but no response was seen and the patient died of EBV-associated lymphoma. It was unclear if VST expansion may have been compromised in this case by the underlying inherent lymphotoxicity of ADA deficiency, as patients remain lymphopenic even in the setting of optimal enzyme replacement therapy. However, the patient with CTPS1 deficiency received 2 doses $\left(2 \times 10 \mathrm{E}^{6} /\right.$ $\mathrm{kg} /$ dose) of 9/10 HLA match EBV-specific T cells and attained a $\mathrm{CR}$, and underwent subsequent HSCT without further viral complications.

\section{HLH With EBV Viremia}

Hemophagocytic lymphohistiocytosis is condition of hyperinflammation associated with immune dysregulation secondary to defects in cytotoxic T lymphocyte and NK cell function. 
HLH can be either primary (associated with a known mutation) or secondary, and EBV viremia is a common trigger. In particular, familial HLH due to mutations in STXBP2 and PRF1 have been associated with chronic EBV viremia (28). Other PIDs have an increased risk of developing HLH, and several are associated with EBV viremia as well as including SAP deficiency, XIAP deficiency, ITK deficiency, and CD27 deficiency. While EBV typically infects B cells, EBV-related HLH is frequently associated with EBV-infected T cells, which presents therapeutic challenges (29). As familial HLH is universally fatal without HSCT as definitive treatment, these patients may benefit from EBV-directed cell therapy to restore EBV-specific immunity early after transplant.

A series of 49 patients who were treated for EBV-LPD following HSCT with donor lymphocyte infusion and/or EBV-specific VST included three patients with PID: one with autoimmune lymphoproliferative syndrome, one with $\mathrm{x}$-linked lymphoproliferative disease, and another had primary HLH. There was an overall response of $68 \%$ following EBV-specific VST infusion, including a $\mathrm{CR}$ in the patient with $\mathrm{HLH}$ who received third party EBV-specific T cells (12). Similarly, Papadopoulou et al. reported a patient with HLH initially treated with multivirus VSTs for HHV6 and BK viremia who subsequently developed EBV reactivation and attained complete clearance of EBV viremia without other EBV-directed therapy after T cell infusion (20). The review by Naik et al. included two patients with HLH and EBV viremia, one of whom attained a CR while the other died of progressive EBV-PTLD (14).

\section{Severe Chronic Active EBV}

Severe chronic active EBV (SCAEBV) infection is a lymphoproliferative disorder characterized by markedly high levels of EBV in blood and tissue that often presents with fever, lymphadenopathy, hepatic dysfunction, and thrombocytopenia (30). In SCAEBV, EBV can infect $\mathrm{T}$ and NK cells in addition to B cells. While the etiology of SCAEBV is often unknown, the underlying defect may represent a type of immunodeficiency. To date, HSCT has shown to be the most effective treatment for SCAEBV. As the primary problem in SCAEBV is an ineffective immune response to EBV, adoptive $\mathrm{T}$ cell therapy with EBV-specific $\mathrm{T}$ cells may be very advantageous in this patient population after HSCT. Heslop et al. included three patients with SCAEBV (one of whom had a known NK cell deficiency) in their trial of 114 patients receiving EBVspecific T cells. One patient was treated on the prophylactic arm and remained free of EBV viremia. Of the two patients with active disease at the time of $\mathrm{T}$ cell infusion, one patient attained a CR while the other died of progressive EBV-associated lymphoma (10). Withers et al. reported a patient with SCAEBV who received third party EBV-specific T cells but died Day +14 after infusion of PD (24).

\section{CHALLENGES AND FUTURE DIRECTIONS}

In spite of the successes with EBV-specific T-cells, there remain limitations in this approach for treatment of PID. Resistance to EBV-specific cellular therapy has been described in several prior studies, which may in some cases relate to viral escape mutations. In one study, a mutation in EBNA-3B enabled viral escape postT-cell therapy (31). The targeted EBV antigens differ slightly between trials, and further studies of the lability of targeted epitopes will be crucial to improve the efficacy of EBV-specific T-cell therapy, particularly in the third-party setting. Best methods of partial HLA matching of third-party EBV-specific T-cells is also unclear, particularly in the setting of rare HLA alleles that are not known to mediate recognition of immunodominant EBV epitopes. EBV-specific T-cells are also subject to inactivation or killing by immunosuppressive therapies, such as corticosteroids, which limits their use in the setting of GVHD following HCT. Genetic modification of antigen-specific T-cells to render them resistant to glucocorticoids and calcineurin inhibitors may enable treatment of PTLD in spite of immunosuppressive therapy $(32,33)$.

It is also unclear if adoptive T-cell therapy will be effective prior to HCT in forms of PID in which APCs are impaired or absent. In a recent study, defects in the costimulatory receptor CD70 resulted in EBV-associated disease (34). CD70 defects could theoretically impair the ability of allogeneic T-cells to lyse infected target cells. EBV-specific T-cells have not been explored in patients with EBV-driven HLH prior to HCT, and is unclear whether partial restoration of cytotoxicity would be of any benefit in this hyper-inflammatory disorder.

Currently, manufacturing of EBV-specific T-cells requires a facility with the ability to meet regulatory guidelines for production of immune effector cells for clinical use. Selection methods allow make use of automated-closed systems, but are expensive and yield low cell numbers. Ex vivo expansion yields higher cell numbers, but requires expertise in more than minimal product manipulation. In both settings, an EBV-seropositive donor would need to be identified for product manufacturing. Third party T-cells circumvent these limitations, but similarly are limited by cost of bank generation and regulatory hurdles that limit widespread availability. New multicenter trials using regional banks will improve accessibility to studies using EBV-specific T-cells. With the recent FDA approval of two chimeric antigen receptor T-cell products, it is hoped that the use of antigen-specific T-cells may similarly be approved in the near future, enabling widespread accessibility to these products.

\section{ETHICS STATEMENT}

This study was carried out in accordance with the recommendations of The National Institutes of Health. The referenced studies were approved by the local Institutional Review Boards. All subjects gave written informed consent in accordance with the Declaration of Helsinki.

\section{AUTHOR CONTRIBUTIONS}

LM prepared the first draft of this manuscript, while MK performed the literature review and compiled the data set of patients 
included in Tables $\mathbf{1}$ and 2. MK and CB both reviewed and edited the final manuscript.

\section{ACKNOWLEDGMENTS}

We would like to thank the staffs of the Divisions of Allergy and Immunology, Oncology, and Blood and Marrow Transplantation, Children's National Medical Center, our collaborators at the Cell and Gene Therapy center at Baylor College of Medicine and other institutions, and the Children's Research Institute. We

\section{REFERENCES}

1. Taylor GS, Long HM, Brooks JM, Rickinson AB, Hislop AD. The immunology of Epstein-Barr virus-induced disease. Annu Rev Immunol (2015) 33:787-821. doi:10.1146/annurev-immunol-032414-112326

2. Gennery AR, Slatter MA, Grandin L, Taupin P, Cant AJ, Veys P, et al. Transplantation of hematopoietic stem cells and long-term survival for primary immunodeficiencies in Europe: entering a new century, do we do better? J Allergy Clin Immunol (2010) 126(3):602-10.e1-11. doi:10.1016/j.jaci.2010.06.015

3. Worth AJ, Booth C, Veys P. Stem cell transplantation for primary immune deficiency. Curr Opin Hematol (2013) 20(6):501-8. doi:10.1097/MOH. ob013e328365a13b

4. Rezvani AR, Maloney DG. Rituximab resistance. Best Pract Res Clin Haematol (2011) 24(2):203-16. doi:10.1016/j.beha.2011.02.009

5. Walter EA, Greenberg PD, Gilbert MJ, Finch RJ, Watanabe KS, Thomas ED, et al. Reconstitution of cellular immunity against cytomegalovirus in recipients of allogeneic bone marrow by transfer of T-cell clones from the donor. N Engl J Med (1995) 333(16):1038-44. doi:10.1056/NEJM199510193331603

6. Riddell SR, Watanabe KS, Goodrich JM, Li CR, Agha ME, Greenberg PD. Restoration of viral immunity in immunodeficient humans by the adoptive transfer of T cell clones. Science (1992) 257(5067):238-41. doi:10.1126/science.1352912

7. Papadopoulos EB, Ladanyi M, Emanuel D, Mackinnon S, Boulad F, Carabasi MH, et al. Infusions of donor leukocytes to treat Epstein-Barr virus-associated lymphoproliferative disorders after allogeneic bone marrow transplantation. N Engl J Med (1994) 330(17):1185-91. doi:10.1056/NEJM199404283301703

8. Haque T, Taylor C, Wilkie GM, Murad P, Amlot PL, Beath S, et al. Complete regression of posttransplant lymphoproliferative disease using partially HLAmatched Epstein Barr virus-specific cytotoxic T cells. Transplantation (2001) 72(8):1399-402. doi:10.1097/00007890-200110270-00003

9. Haque T, Wilkie GM, Jones MM, Higgins CD, Urquhart G, Wingate P, et al. Allogeneic cytotoxic T-cell therapy for EBV-positive posttransplantation lymphoproliferative disease: results of a phase 2 multicenter clinical trial. Blood (2007) 110(4):1123-31. doi:10.1182/blood-2006-12-063008

10. Heslop HE, Slobod KS, Pule MA, Hale GA, Rousseau A, Smith CA, et al. Longterm outcome of EBV-specific T-cell infusions to prevent or treat EBV-related lymphoproliferative disease in transplant recipients. Blood (2010) 115(5): 925-35. doi:10.1182/blood-2009-08-239186

11. Bollard CM, Gottschalk S, Torrano V, Diouf O, Ku S, Hazrat Y, et al. Sustained complete responses in patients with lymphoma receiving autologous cytotoxic T lymphocytes targeting Epstein-Barr virus latent membrane proteins. J Clin Oncol (2014) 32(8):798-808. doi:10.1200/JCO.2013.51.5304

12. Doubrovina E, Oflaz-Sozmen B, Prockop SE, Kernan NA, Abramson S, TeruyaFeldstein J, et al. Adoptive immunotherapy with unselected or EBV-specific T cells for biopsy-proven EBV+ lymphomas after allogeneic hematopoietic cell transplantation. Blood (2012) 119(11):2644-56. doi:10.1182/blood-2011-08-371971

13. Leen AM, Bollard CM, Mendizabal AM, Shpall EJ, Szabolcs P, Antin JH, et al. Multicenter study of banked third-party virus-specific $\mathrm{T}$ cells to treat severe viral infections after hematopoietic stem cell transplantation. Blood (2013) 121(26):5113-23. doi:10.1182/blood-2013-02-486324

14. Naik S, Nicholas SK, Martinez CA, Leen AM, Hanley PJ, Gottschalk SM, et al. Adoptive immunotherapy for primary immunodeficiency disorders with virus-specific T lymphocytes. J Allergy Clin Immunol (2016) 137(5): 1498-505.e1. doi:10.1016/j.jaci.2015.12.1311 would like to thank the Lymphoma Research Foundation and the Jeffrey Modell Foundation for their support of LM and MK and this work.

\section{FUNDING}

This research was funded by grants from the National Institutes of Health (U54 HL081007 to CB; K23- HL136783-01 to MK), the National Cancer Institute (PO1 CA148600e02 to CB), and the Jeffrey Modell Foundation.

15. McLaughlin LP, Bollard CM, Keller M. Adoptive T cell immunotherapy for patients with primary immunodeficiency disorders. Curr Allergy Asthma Rep (2017) 17(1):3. doi:10.1007/s11882-017-0669-2

16. Hislop AD, Taylor GS, Sauce D, Rickinson AB. Cellular responses to viral infection in humans: lessons from Epstein-Barr virus. Annu Rev Immunol (2007) 25:587-617. doi:10.1146/annurev.immunol.25.022106.141553

17. Neudorfer J, Schmidt B, Huster KM, Anderl F, Schiemann M, Holzapfel G, et al. Reversible HLA multimers (Streptamers) for the isolation of human cytotoxic T lymphocytes functionally active against tumor- and virus-derived antigens. J Immunol Methods (2007) 320(1-2):119-31. doi:10.1016/j.jim.2007. 01.001

18. Feuchtinger T, Lucke J, Hamprecht K, Richard C, Handgretinger R, Schumm M, et al. Detection of adenovirus-specific $\mathrm{T}$ cells in children with adenovirus infection after allogeneic stem cell transplantation. Br J Haematol (2005) 128(4):503-9. doi:10.1111/j.1365-2141.2004.05331.x

19. Feucht J, Joachim L, Lang P, Feuchtinger T. Adoptive T-cell transfer for refractory viral infections with cytomegalovirus, Epstein-Barr virus or adenovirus after allogeneic stem cell transplantation. Klin Padiatr (2013) 225(3):164-9. doi:10.1055/s-0033-1333749

20. Papadopoulou A, Gerdemann U, Katari UL, Tzannou I, Liu H, Martinez C, et al. Activity of broad-spectrum T cells as treatment for AdV, EBV, CMV, BKV, and HHV6 infections after HSCT. Sci Transl Med (2014) 6(242):242ra83. doi:10.1126/scitranslmed.3008825

21. Leen AM, Christin A, Myers GD, Liu H, Cruz CR, Hanley PJ, et al. Cytotoxic $\mathrm{T}$ lymphocyte therapy with donor $\mathrm{T}$ cells prevents and treats adenovirus and Epstein-Barr virus infections after haploidentical and matched unrelated stem cell transplantation. Blood (2009) 114(19):4283-92. doi:10.1182/ blood-2009-07-232454

22. Vickers MA, Wilkie GM, Robinson N, Rivera N, Haque T, Crawford DH, et al. Establishment and operation of a good manufacturing practice-compliant allogeneic Epstein-Barr virus (EBV)-specific cytotoxic cell bank for the treatment of EBV-associated lymphoproliferative disease. Br J Haematol (2014) 167(3):402-10. doi:10.1111/bjh.13051

23. Wynn RF, Arkwright PD, Haque T, Gharib MI, Wilkie G, Morton-Jones M, et al. Treatment of Epstein-Barr-virus-associated primary CNS B cell lymphoma with allogeneic T-cell immunotherapy and stem-cell transplantation. Lancet Oncol (2005) 6(5):344-6. doi:10.1016/S1470-2045(05)70171-6

24. Withers B, Blyth E, Clancy LE, Yong A, Fraser C, Burgess J, et al. Long-term control of recurrent or refractory viral infections after allogeneic HSCT with third-party virus-specific T cells. Blood Adv (2017) 1:2193-205. doi:10.1182/ bloodadvances. 2017010223

25. Hutspardol S, Essa M, Richardson S, Schechter T, Ali M, Krueger J, et al. Significant transplantation-related mortality from respiratory virus infections within the first one hundred days in children after hematopoietic stem cell transplantation. Biol Blood Marrow Transplant (2015) 21(10):1802-7. doi:10.1016/j.bbmt.2015.06.015

26. Odek C, Kendirli T, Dogu F, Yaman A, Vatansever G, Cipe F, et al. Patients with primary immunodeficiencies in pediatric intensive care unit: outcomes and mortality-related risk factors. J Clin Immunol (2014) 34(3):309-15. doi:10.1007/s10875-014-9994-6

27. Pai SY, Logan BR, Griffith LM, Buckley RH, Parrott RE, Dvorak CC, et al. Transplantation outcomes for severe combined immunodeficiency, 2000-2009. NEngl J Med (2014) 371(5):434-46. doi:10.1056/NEJMoa1401177 
28. Parvaneh N, Filipovich AH, Borkhardt A. Primary immunodeficiencies predisposed to Epstein-Barr virus-driven haematological diseases. Br J Haematol (2013) 162(5):573-86. doi:10.1111/bjh.12422

29. Kasahara Y, Yachie A. Cell type specific infection of Epstein-Barr virus (EBV) in EBV-associated hemophagocytic lymphohistiocytosis and chronic active EBV infection. Crit Rev Oncol Hematol (2002) 44(3):283-94. doi:10.1016/ S1040-8428(02)00119-1

30. Cohen JI, Jaffe ES, Dale JK, Pittaluga S, Heslop HE, Rooney CM, et al. Characterization and treatment of chronic active Epstein-Barr virus disease: a 28-year experience in the United States. Blood (2011) 117(22):5835-49. doi:10.1182/blood-2010-11-316745

31. Gottschalk S, Ng CY, Perez M, Smith CA, Sample C, Brenner MK, et al. An Epstein-Barr virus deletion mutant associated with fatal lymphoproliferative disease unresponsive to therapy with virus-specific CTLs. Blood (2001) 97(4):835-43. doi:10.1182/blood.V97.4.835

32. Brewin J, Mancao C, Straathof K, Karlsson H, Samarasinghe S, Amrolia PJ, et al. Generation of EBV-specific cytotoxic T cells that are resistant to calcineurin inhibitors for the treatment of posttransplantation lymphoproliferative disease. Blood (2009) 114(23):4792-803. doi:10.1182/blood-2009-07-228387
33. Menger L, Gouble A, Marzolini MA, Pachnio A, Bergerhoff K, Henry JY, et al. TALEN-mediated genetic inactivation of the glucocorticoid receptor in cytomegalovirus-specific T cells. Blood (2015) 126(26):2781-9. doi:10.1182/ blood-2015-08-664755

34. Abolhassani H, Edwards ES, Ikinciogullari A, Jing H, Borte S, Buggert M, et al. Combined immunodeficiency and Epstein-Barr virus-induced B cell malignancy in humans with inherited CD70 deficiency. JExp Med (2017) 214(1):91-106. doi:10.1084/jem.20160849

Conflict of Interest Statement: The authors declare that the research was conducted in the absence of any commercial or financial relationships that could be construed as a potential conflict of interest.

Copyright (c) 2018 McLaughlin, Bollard and Keller. This is an open-access article distributed under the terms of the Creative Commons Attribution License (CC $B Y)$. The use, distribution or reproduction in other forums is permitted, provided the original author(s) and the copyright owner are credited and that the original publication in this journal is cited, in accordance with accepted academic practice. No use, distribution or reproduction is permitted which does not comply with these terms. 